\title{
Tipleri Yeniden Düşünmek: Mimari Tasarım Stüdyoları İçin Tip Odaklı Bir Pedagoji Önerisi
}

\author{
Rethinking Types: A Pedagogical Proposal For Design Studios That Focus On Typology
}

(1) Altuğ KASALI

Mimarlık disiplini içinde farklı zaman dilimlerinde tekrarlanan bir tartışma konusu olarak karşımıza çıkan tip ve tipoloji kavramları makalenin ana konusunu oluşturur. Tasarım süreçlerine dair analitik bir kavram olarak tanımlanabilecek tip için çeşitli tanımlar bulunsa da, tasarımcıların tipleri nasıl araçsal hale getirip kullandığı farklııklar gösterir. Bu makalede öncelikle tip üzerine birikmiş literatüre dair kısa bir döküm sunulacaktır. Ardından, farklı dönemlerde tipleri tasarım uygulamaları içerisinde ana eksene alan mimarların işlerinden bahsedilecektir. Kuram ve uygulama yaklaşımları üzerinden gidilerek, tipleri tasarım süreçleri içerisinde ana eksene alan bir tasarım stüdyosu pedagojisinin ana hatlarına yer verilecektir. Son olarak, tiplerin tasarım süreçlerindeki rolü üzerine kısa bir değerlendirme sunulacaktır.

Anahtar sözcükler: Mimarlık; tasarım stüdyosu; tipoloji.

\section{ABSTRACT}

Typology - as an analytical concept to inform our understanding of design- has been a recurring discussion topic in architectural circles. While there are several canonical sources to conceptualize the idea of type, how designers frame the term and instrumentalize it varies significantly. The paper initially presents a quick account of the trajectory of typological approaches, particularly in architecture, and provides a range of formulations offered by both theoreticians and practitioners. Then, a range of cases -involving both historic and contemporary practices- will be elaborated to demonstrate how the notion of type is manifested in the work of key designers. Building up on the diverse formulations of type in existing literature, the paper offers an instrumental conceptualization of type in the context of design studio pedagogy. Finally, the paper will present a concise assessment on the role of types in design processes.

Keywords: Architecture; design studio; typology. 


\section{Giriş}

"...sonuç olarak yaratıcı süreçlerin tipolojik ve buluşsal yönleri sürekli ve birbirine geçmiş haldedir."

Tasarım süreçlerini şekillendiren veya dönüştüren bir kavram olarak tipoloji, mimarlık disiplini içinde farklı zaman dilimlerinde tekrarlanan bir tartş̧ma konusu olarak karşımıza çıkmaktadır. Tip düşüncesini oluşturan çeşitli kanonik kaynaklar olmasına rağmen, ${ }^{2,3}$ tasarımcıların bu terimi nasıl kavradığı ve araçsallaştırdığı ciddi farklılıklar göstermektedir. Tasarım araştırmaları ve uygulamaları, tip teriminin ele alınışındaki çeşitlenmeyi gösteren örneklerle doludur. Bu makalede öncelikli olarak tip kavramının, özellikle mimarlık alanında farklı tasarımcılar ve kuramcılar tarafindan nasıl formüle edildiğine dair bir arka plan sağlanacaktır. Bunun ardından tip kavramını yaratıcı süreçlerinde irdelemiş tasarımcıların işlerine analitik bir bakış açısı sunulacaktır. Son kısımda ise literatürde ön plana çıkan farklı tipolojik yaklaşımlar göz önünde bulundurarak oluşturulmuş bir pedagojik çerçevenin detayları sunulacaktır. Lisans düzeyinde bir tasarım stüdyosunda uygulaması yapılan bu yaklaşım, tiplerle düşünmenin katılımcıların ürettikleri işlerin yaratıcılık bağlamında bir çeşitlenmeye yol açthğı savını desteklemesi açısından önemlidir.

Mimarlık kuramı ve uygulamasının kilit terimlerine dair bir döküm sunan Adrian Forty, ${ }^{4}$ kitabında tip kelimesine nasıl anlamlar yüklendiğini tartışır. Buna göre, tipolojik sınıflandırmanın temelde iki şema üzerinden ilerlediğini önerir; illk olarak Pevsner'in ${ }^{5}$ "yapı tiplerinin tarihi" kitabında takip ettiği rotaya referansla binaların kullanımına dair bir sınıflamanın varlığı sözkonusudur. Bu anlamda yapılar, okul, hastane, konut gibi kategorilere ayrilabilmekteydi. Forty'nin bahsettiği bir diğer yöntem ise yapılara biçimsel (morfolojik) kalitelerine göre bakabilmekten geçiyordu. Bu bakışa göre ise yapılar için merkezi planlı, avlulu, ayrık düzenli gibi tiplerden söz edilebilirdi. Kavramın literatürde farklılaşan karşılıkları da düşünülerek, tip için keskin bir tanımlama yapmanın zorluğ ${ }^{6}$ bilinmektedir. Bu makalede ele alındığı şekli ile tip, mimari tasarım bağlamında biçimsel olarak sınıflandırılmaya referans ile kurgulandığı düşünülebilir.

\section{Yinelenen Bir Tema Olarak Tipoloji}

Sıkça referans verildiği üzere, Aydınlanma Dönemi'nin Fransız entelektüellerinden Antoine-Chrysostôme Quatremère de Quincy tip terimini tasarım kelime hazinesine kazandıran isim olarak bilinir. Uzun bir akademik uğraşın ürünü olarak 1832 'de yayınlanan mimarlık ansiklopedisinde (Dictionnaire historique d'architecture), Quatremère, ${ }^{2}$ tip terimini bilinçli bir şekilde model ile karşılaştırarak tanımlar. Buna göre tip, bir unsura ait temel

\footnotetext{
1 Argan, 1996, s. 246.

Quatremère, 1832, s. 629. ${ }^{3}$ Rossi, 1982.

4 Forty, 2000, s. 305.

5 Pevsner, 1976.

6 Jacoby, $2015 a$.
}

kuralları temsil eden görece soyut bir fikri veya düşünceyi belirtmektedir. Quatremère'e göre model ise, söz konusu unsuru çeşitlenmeye çok olanak vermeyen taklitlerine (imitation) işaret etmektedir. Bu anlamda tip, mekanik bir yeniden üretim olan modelden farklı olarak, belirli bir imajı tarif eden reçeteden çok, söz konusu olguya ait fikre veya kurguya referans veren bir kavramı tanımlamaktaydı. Quatremère'in tariflediği tip kavramına dair en önemli potansiyel ise bir olguyu temsil eden kural veya kuralları koruyarak yaratılabilecek çeşitlemelerin de tipolojik olarak aynı sınıfta bulunabilecek olmasıdır.

Quatremère yazılarında tipin ne olduğuna dair bir açıklama sunarken, tipler veya tipolojik kategoriler ile neler yapılabileceğine dair öneriyi geliştiren ise 19. yüzyıl entelektüel ortamının bir diğer kuramcısı Jean-Nicolas-Louis Durand'dır. Durand'ın, zengin görsellerle desteklenen tipolojik (veya biçimsel) sınıflandırması, yapı bileşenlerinin veya daha genel olarak yapıların, kompozisyon stratejilerine dair bir analitik ve ilerici bir metod sunması açısından çok önemlidir. Durand ${ }^{7}$ temel olarak, kendi sözleriyle, "güvenli ve hızlı bir biçimde, her zamanda, her yerde, her türden binayı tasarlamak ve inşa etmek için" bir metoda duyulan intiyaç ile ilgilenmektedir. Quatremère tarafindan daha soyut bir kavram olarak sunulan tip, Durand'ın önerisinde materyal bir karşlık bulmaya başlar. Bu eksende ele alınan tip ve tipoloji düşüncelerinin önemine, modern ve modern sonrası dönemin birçok yazarı da vurgu yapmış$\operatorname{trr}^{8,9}$

Tipolojik düşünmenin veya akıl yürütmenin tasarım süreçleri ile ilişkisini çerçevelemek açısından Durand'ın tezinden biraz daha bahsetmekte fayda var. Paris Politeknik Okulu'nda verdiği derslerin bir özeti olarak yayınlanan eserler (Précis des leçons d'architecture), Durand'ın yöntem ve pedagoji yaklaşımlarını anlayabilmemiz için kaynak oluşturur. Durand'ın tezinin en kritik önerisi tasarımın temelde bir kompozisyon meselesi olarak düşünülmesi ve tasarımcının manevra alanını belirleyecek bir altlı̆ın (ızgara sistem veya yapısal akslar) ve elemanların (kolon, kiriş, kemer vb...) bir kompozisyon stratejisi takip edilerek yapıya dair bileşenleri oluşturması olarak özetlenebilir. Bu sayede, yukarıda bahsedilen altık ve elemanlarla oluşturulan yapı parçaları (veranda, giriş, hol, merdiven şemaları, vb...) mimarın emrine yapıların bütününü tasarlamaları için farklı ölçeklerde tipolojik bir repertuar veriyordu. Jacoby'nin ${ }^{10}$ makalesinde vurguladığı üzere, Durand, bir tip tanımı oluşturmaktan çok, tipler üzerinden düşünmenin (veya tipolojik akıl yürütmenin) tasarım sürecinde nasıl araçsal hale gelebileceği üzerine tasarımcılar için bir ufuk açıyordu. Bu makale özelinde ise, Durand'ın tipolojik düşünce yaklaşımının her zaman grafik kataloglar halinde sunuluyor olması vurgulanması gereken bir noktadır. Durand'ın önerdiği ka-

Durand, 2000, s. 77. ${ }^{8}$ Moneo, 1978. ${ }^{9}$ Vidler, 1996, s. $13 .{ }^{10}$ Jacoby, 2015 b. 
talogların, yapılar için kompozisyon anlamında, belki de, sınırlı bir çözüm havuzu sunuyor olması yaratıcılık anlamında bir eleştiri konusu olduğu düşünülebilir. Fakat, bir sınıflandırma çerçevesinde sunulan yapı bileşenlerine ait -çoğunlukla ortografik olarak üretilmiş- grafik temsillerin (representation) tasarım sürecinin asal bir parçası olarak ayırt edilmesi önem taşımaktadır.

Vidler, Quatremère ve Durand ekseninde tartşılan tipoloji kavramının, modernizm çerçevesinde daha kapsamlı bir tartışmaya açıldığından bahseder. Vidler'e göre, çağın yeni gelişen üretim teknolojilerinden esinlenerek tekrar formüle edilen tip düşüncesi, Le Corbusier'in Dom-İno Evi önerisi ile iyi bir şekilde örneklenmişti. Picon ${ }^{11}$ tarafindan bir arketip olarak sunulan Dom-Ino Evi, birbirine paralel üç plaka, plakaları ilişkilendiren bir merdiven, alt kolon ve bir temel sistemi ile temsil edilmekteydi. Picon'a göre bu tip kavramsallaştirması bir "jenerik bir durum" (generic condition) veya "açık bir kalkış noktası" (open point of departure) olarak tanımlanabilirdi.

Le Corbusier'in fikri, yukarıda bahsi geçen yapısal ilişkileri belirlenmiş bir organizasyondan (tip) yola çıkılarak, endüstriyel yöntemlerle üretilen diğer yapı bileşenlerinin entegrasyonu ile elde edilecek çeşitlemelerin konut ihtiyacının hızlı bir biçimde karşılanmasını öngörüyordu. Bu anlamda Le Corbusier'in önerdiği tip, farklılaşmalara olanak veren temel prensiplerin temsil edildiği bir kavrama işaret etmekteydi. Daha önceleri farklı ölçeklerdeki seri üretim tasarım nesneleri (objets-type) üzerinden tartısıılan tip meselesi, Le Corbusier'in Dom-İno Evi'nde sunduğu fikirleri başka projelerinde çeşitlendirip uygulamaya geçirmesi ile mimarlık özelinde de asal bir konu olarak kendine tekrar yer buldu. ${ }^{12}$

Tip ve tipoloji üzerine odaklanan kuramsal tartş̧malarda en üretken dönem olarak $60^{\prime}$ ların sonu ve $70^{\prime}$ lerin başı referans verilir. Vidler, ${ }^{9}$ bu dönemi, köklerini Aydınlanma felsefesinde olgunlaşan ilk fikirlerin, ve akılcı üretim yöntemleri ile ilişkilenen modernist yaklaşımın ardından gelen ve eleştirel yaklaşımı ile ayırt edilebilecek "üçüncü tipoloji" olarak adlandırır. Bu dönemin en kilit ismi ise mimar-kuramcı Aldo Rossi olarak öne çıkar. Rossi'nin kuramsal altyapısını büyük oranda oluşturduğu "üçüncü tipoloji", ana eksenini geleneksel kent dokusuna ve formlarına analitik bir yaklaşımla bakan bir tasarım çerçevesi olarak algılanabilirdi. Rossi'ye ${ }^{13}$ göre tip, "kalıcı ve karmaşık" bir altılığa ve "formu oluşturan mantıksal prensibe" işaret etmekteydi. Tip kavramını "mimarlığa temeli" olarak tanımlayan Rossi, kendi mimarlık üretiminde de tipoloji eksenindeki kavramsal ilgisini genişletebileceği bir alan bulabilmişti. Rossi'nin 1970'lerin başında tamamladığı San Cataldo Mezarlığı projesi, bu anlamda mimarın tip kavramını araçsal hale getir-

\footnotetext{
${ }^{11}$ Picon, 2014, s. $172 . \quad{ }^{12}$ Forty, 2000, s. $307 . \quad{ }^{13}$ Rossi, 1982, s. 40.
}

diği özel bir örnek olarak literatürde sıkça referans verilmiştir.

Rossi'ye göre tipler, işlevi bir değişken alacak şekilde yapılarda, kentsel mekânlarda veya parçlarda bir süreklilik içinde gözlemlenebilirdi. Bu gözlemi veya tanımlamayı yapabilmek elbette sistematik bir inceleme gerekliydi. Bu anlamda tipoloji, kent parçaları veya yapılar için daha fazla indirgenemeyecek parçalara dair analitik çalışmalar bütünüydü. Rossi kitabında kentsel ve tarihsel süreklilik içerisinde incelediği tiplere örnekler vererek kuramını desteklemekteydi. ${ }^{14}$ Rossi'nin tipler için öne sürdüğü en önemli mesele ise, bunların sadece fiziksel nesneler olarak değerlendirilmekten öte, kentsel uygulamalar ile ilişkide olan, kentsel tarih ve coğrafya üzerinden okumamı gereken nesneler olduğunu düşünmemizi vurgulaması olmuştur.

Tipolojik yaklaşımı merkez alarak yapılan çalışmalar post-modern dönemdeki sıcaklığı ile gündemde olmasa da, tip-mimari ilişkisi güncellenmiş bir tasarım tartşması olarak önümüze çıkar. Peter Carl, ${ }^{15}$ biçimsel tiplerin dijital imkânlarla parametrik kontrolünü sağlama becerisinin günümüz tasarımcıları için yeni açıımlar sunduğundan bahseder. Gerçekten de, özellikle mimari tasarım konusunda farklı alanlardaki fikirlere referansla düşünülen belirli topolojik nesnelerin (örneğin Mobius şeridi veya Klein şişesi), tasarım süreçleri için belirli biçimsel tipler sunduğu gözlemlenebilir. Örneğin, yenilikçi tasarımları ile dikkat çeken Caroline Bos ve Ben van Berkel ${ }^{16}$ (UNStudio), ön plana çıkan büyük ölçekli projelerinin bazılarında mimari üretimlerini yukarıda bahsedilen tipler üzerinden açıklar. Bos ve van Berkel, dijital teknolojilerle ürettikleri ve "manipüle" ettikleri biçimsel tiplerin araçsal kabiliyetleri ile tasarımları yönlendirdiğinden bahseder.

Bos ve van Berkel'in bahsettikleri tip ile Quatremère'in tanımladığı tip elbette ki farklı entelektüel iklimlerin ürünüdür. Bu iki tanımının arasında iki yüzyıla yakın bir süre ve mimari tasarım ekseninde birçok farklı tip yorumunun olduğu görülebilir. Bu anlamda farklı yaklaşımlarla tanımı dönüşen bu kavramın akademik bir tartışma konusu olarak sürekliliğinin olduğu ve tasarım pratiği açısından da üretken bir zemin oluşturduğu söylenebilir. Bir sonraki kısımda, tasarım süreçleri içinde tip kavramının farklı mimarlar tarafindan -kuram ile de ilişkilendirerek- nasıl araçsal hale getirildiğine dair örneklerden bahsedilecektir.

\section{Temsil ve Uygulama Aracı Olarak Tipler}

Mimari tasarım özelinde, tiplerin tasarım süreçlerine nasıl entegre edildiği sorusu öncelikle bir ölçek kavrayışının ortaya konulmasını gerektirir. Mimari tipler ile kastedilen, Durand'ın katalogladığı yapı bileşenleri midir? Yok-

\footnotetext{
${ }^{14}$ Padova'daki Palazzo della Ragione veya Luc- ${ }^{15}$ Carl, 2011, s. 39. ca'daki Roma amfitiyatrosu Rossi'nin verdiği ${ }^{16}$ Bos ve van Berkel, 2011. örneklerden ikisidir.
} 


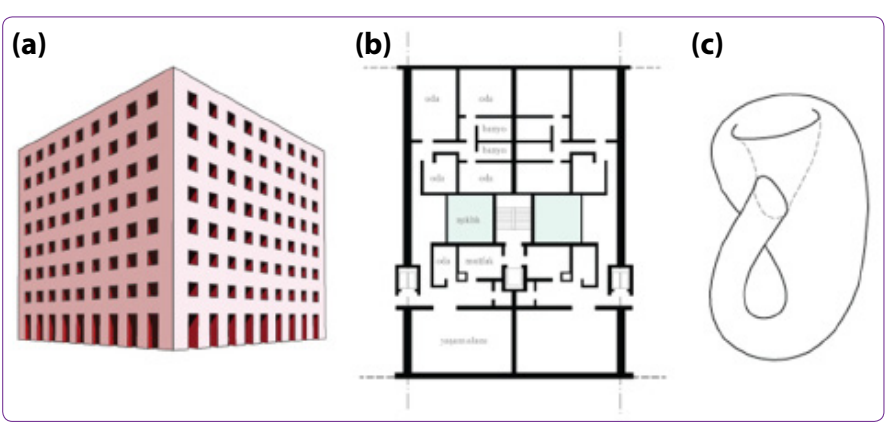

Şekil 1. Tip anlayışının üç farklı mimarın tasarım süreçleri içindeki temsilleri; (a) Aldo Rossi, (b) Rafael Moneo, (c) UN Studio (Çizimler yazar tarafından üretilmiştir).

sa, Forty'nin merkezi planlı veya avlulu şeklinde tariflediği yapı ölçeğindeki sınıflandırma mıdır? Tip kavramına çok farklı bir açıdan yaklaşsa da, bu soruya en net cevabı Giulio Carlo Argan verir. Argan'a ${ }^{17}$ göre biçimsel bir çerçeveden bakılınca tiplerin sınıflandırmasına dair üç analitik seviye ortaya çıkmaktadır. Illk olarak yapının bir bütün olarak düzenlenme biçiminden (konfigürasyon) bahsedilebilir. Örneğin, merkezi plan düzeni (rotonda) veya uzatılmış prizma formu (bazilika), tarihsel olarak da tekrar eden yapı tipleri olarak sayılabilir. Bir diğer seviye olarak Argan, temel yapısal elemanları işaret eder. Mimarlık özelinde kırma çatılar veya kubbeler farklı tipler olarak ayrışır. ${ }^{18}$ Argan, önerdiği seviyelerin son halkası olarak dekoratif elemanları ön plana çıkarır. Buna göre, Dor, lyonik, Korint gibi kolon düzenlerine veya benzeri ölçeklerdeki süsleme detaylarına ilişkin sınıflandırmalarda da tiplerden söz edilebilir.

Argan'ın tariflediği kategoriler, mimarın farklı ölçeklerde takip edilebilecek tiplerin şekillendirdiği doğrusal bir tasarım yöntemi önerir. Bu genel olarak kabul görebilecek bir önerme olsa da, pratikte mimarların neyi tip olarak sınıflandırdığına ve bu tipleri yaratıcı tasarım yaklaşımları ile nasıl işlediğine (manipülasyon) dair kapsamlı bir kuramın varlığından söz edemeyiz. Tasarım süreçlerine odaklanan yayınlar ise bize tip anlayışının biçimsel tezahürlerinin, farklı tasarım temsil sistemleri üzerinde öznel bir biçimde işlenmesi yolu ile ilerlediğini göstermektedir. Aşağıda kısaca bahsedilen örnekler (Şekil 1), mimarların uygulamalarında tipleri nasıl çerçeveledikleri ve operasyonel hale getirdiklerini gösteren çeşitli yaklaşımlardan sadece üç tanesidir.

Aldo Rossi, daha önce de bahsedildiği üzere, mimarlıkta tip üzerine yoğun tartş̧maların yapıldığı yıllarda ürün veren pratisyen ve kuramcı olarak ön plana çıkar. Rossi, ${ }^{19}$ tipleri kentsel repertuarın ve hafizanın tekrar eden parçaları olarak görür. Kendilerine has biçimleri, dokuları, ve

\footnotetext{
${ }^{17}$ Argan, 1996, s. 244.

18 Rafael Moneo dönüşen tiplerden larından bahseder.

bahseder ve bahsedilen kubbe ti- ${ }^{19}$ Rossi, 1982.

pinin Rönesans, Rönesans-sonrası,
}

renkleri ile var olan tipler, Rossi'nin mimari kompozisyonlarının kilit parçalarıdır. Örneğin, bu makalede daha önce de bahsedilen San Cataldo Mezarlığı'nın ana ekseni üzerinde belirli bir düzen içerisinde konumlanan parçalar (Şekil 1a), tiplerin tasarım süreçleri içindeki anahtar rolünü anlamamı için bir örnek oluşturur. Projenin inşa edilmiş yapılarının ötesinde, mimarın tipolojik araştırmalarını ve kompozisyon niyetlerini göstermesi bakımından ürettiği çizimler ${ }^{20}$ iyi bir kaynak oluşturur. Bireysel olarak incelikle tasarlanan tipolojik elemanlar, bir araya gelişleri ile de kentsel deneyimlere referans verir. Rossi'nin çizimleri, ayrık bir şekilde de düşünülebilen mimari tipleri mezarlığın merkezi aksı boyunca mekânsal bir süreklilik sağlayacak şekilde tekrar nasıl kompoze edildiğine dair niyetleri ortaya koyar. Farklı işlevler için düşünülmüş bu elemanlar -çatısız ve düzenli pencereleri olan bir küp, boyutları bir aks boyunca farklılaşan prizmalar, gökyüzüne açılan konik kule - bir araya gelme stratejileri ile beraber de düşünüldüğünde farklı kentsel, yapısal ve bilişsel katmanları sentezleme gücü bakımından ilgi çekicidir. Bu anlamda Rossi'nin, kendinden önceki modern tasarımcılardan farklı bir mimarlık kuramının hatlarını çizmesinin yanında, mimari tipleri merkeze alarak önerdiği tasarım yaklaşımı farklı ölçekleri (kent, yapı, yapı parçaları) ilişkilendirir. Rossi'nin tarihsel referanslarla ilişkilenen tipleri, mimarın kompozisyonlarının düzenleyici üç boyutlu elemanları olarak önem kazanır.

Rafael Moneo, kuramsal üretiminin yanında tasarımlarında da tip kavramını vurgulayan mimarlardan bir diğeridir. Moneo, ${ }^{21}$ mimari ürünlerin tipler yolu ile tanımlanmasının ötesinde, mimarinin aslında tipler üzerinden üretildiğini savunur. Moneo, tipleri "donmuş mekanizmalar" olarak ele almayıp, onları çeşitlemelere olanak veren bir çerçeve olarak tasarım süreçlerinin entegre bir parçası olarak sunar. Moneo, ${ }^{22}$ görece yeni sayılacak bir makalesinde, tipe dair düşüncelerin temsiller üzerinden farklı yönlere esneyebileceğini gösteren örnekler sunar. Bunlardan en ilginci ise, mimarın San Sebastian'da tasarladığı konut bloğunda önerdiği tipolojik müdahaledir. Moneo, süregelen yerleşik bir konut tipinin, planimetrik bir müdahale ile nasıl farklılaşabileceğini gösterir. Burada bu makaleyi ilgilendiren kritik mesele ise Moneo'nun belirli bir tip üzerine geliştirdiği düşünceleri iki boyutlu ortografik bir plan çizimi üzerinden tartışmasıdır (Şekil 1b). Moneo'nun plan çizimini ön plana alması, Rossi örneğinde bahsedilen yaklaşım ile tasarımın temsili anlamında belirgin bir farklılık gösterir. Moneo'nun yerleşik plan tipi üzerinden yaptğ̆ı önerme, önerdiği mekanlardaki kullanım alışkanlıkları ve mahremiyeti etkileyecek kritik bir müdahale olarak görülebilir.

\footnotetext{
${ }^{20}$ Aldo Rossi Vakfínın arşivi özellik- opere/1970-1979/cimitero-di-sanle bu projeyi anlamak için iyi bir cataldo-modena-1971-1978-2/ kaynaklar bütünü sunar. https:// ${ }^{21}$ Moneo, 1978, s. 23. www.fondazionealdorossi.org/ ${ }^{22}$ Moneo, 2015.
} 
Tiplerin tasarım süreçlerindeki araçsal rolü güncel örneklerde de gözlemlenebilir. Yukarıda da bahsedilen mimarlar, Caroline Bos ve Ben van Berkel ${ }^{23}$ (UN Studio), tasarımlarında tipolojik düşünce yaklaşımlarını ön plana çıkartthkları görülmektedir. Mimarların, Arnhem Ulaşım merkezi önerisi iki farklı biçimsel tipten - $V$ formu ve Klein şişesi- faydalanan bir proje olarak öne çıkar. Kendi kullandıkları tarifle bu iki tipten " $V$ " formu, taşıyıcı sistemde ifadesini bulmaktadır. Sözü geçen proje için tasarımın genel karakterinin oluşmasına referans olarak ise topolojik bir nesne olarak Klein şişesini bir tip olarak sunarlar (Şekil 1c). Sürekli yüzeylerin varlığı ile iç-dış ayrımını kaldıran bir geometrinin ifadesi olan Klein şişesi, mimarların tasarım süreçleri içinde yaptı̆̆ form denemelerinin odağında yer alır. UN Studio, kullanılan bu tipi, takip ettikleri tasarım süreçleri içinde yapının bulunduğu bağlama, kullanıcıya ve mekân kurulumunu etkileyecek diğer faktörlere göre tekrar değerlendirir ve mekânsal bir anlam kazandırır. Klein Şişesi gibi üç boyutlu sofistike bir nesnenin Arnhem projesi için neden seçildiği çok belirgin olmasa da, kullanılan bu tipin tasarım süreci içinde -sadece biçimsel bir esinlenmenin ötesinde- bir çıkış noktası olduğu ve sürecin önemli bir bileşeni olarak araçsal hale geldiği söylenebilir.

Tiplerin tasarım süreçleri içerisinde farklı ele alınma biçimleri bahsedilen bu üç kısa örnekten çok daha fazlası ile açıklanabilir. Fakat bu örnekler, tip anlayışının farklı mimarlarda farklı temsiller üzerinden işlenmesi ve araçsal hale gelmesi anlamında yeterli fikir vermektedir. Rossi'nin kompozisyonlarındaki tarihsel ve kentsel referanslarla yüklü parçalar, Moneo'nun iki boyutlu plan kurulumu üzerine getirdiği yorum, veya UNStudio'nun dijital yöntemlerle dönüştürdüğü Klein şişesi, tiplerin farklı yöntemlerle temsili ve yaratıcı bir şekilde kullanılması üretken bir tip kavramının odağa alındığı tasarım yöntemini tarifler.

\section{Pedagojik Bir Araç Olarak Tipler}

Yukarıda sunulan kısa özetten sonra, tip kavramının mimarlık kuramı ve uygulaması boyutunda belirgin bir yeri olduğu daha rahat savunulabilir. Fakat tasarım eğitimi perspektifinden bakıldığında, tip kavramının pedagojik anlamda ne kadar vurgulandığı konusunda çok yoğun bir arka plan bulunmamaktadır. Tip üzerine düşüncelerin eğitim alanında tartışıldığı erken örneklerden biri, 1980'lerin başında, konunun uygulamada hala sıcak olduğu bir dönemde yayınlanan akademik dergilerden birinin (The Journal of Architectural Education) özel sayısıdır. Derginin editörleri, ${ }^{24}$ biraz da provakatif bir tonla, yayınlanan makalelerin "mimarlık eğitiminin esas konularından biri olarak kabul etmediği tipoloji konusu ile uğraştğından" bahseder. Bu yaklaşım, editörlerin mimarlık içindeki tipolojik düşünce biçimlerinin modası geçmiş bir tartş̧malar bütünü ol-

\footnotetext{
${ }^{23}$ Bos ve van Berkel, 2011, s. $73 . \quad{ }^{24}$ Morris \& Levin, 1982, s. 1
}

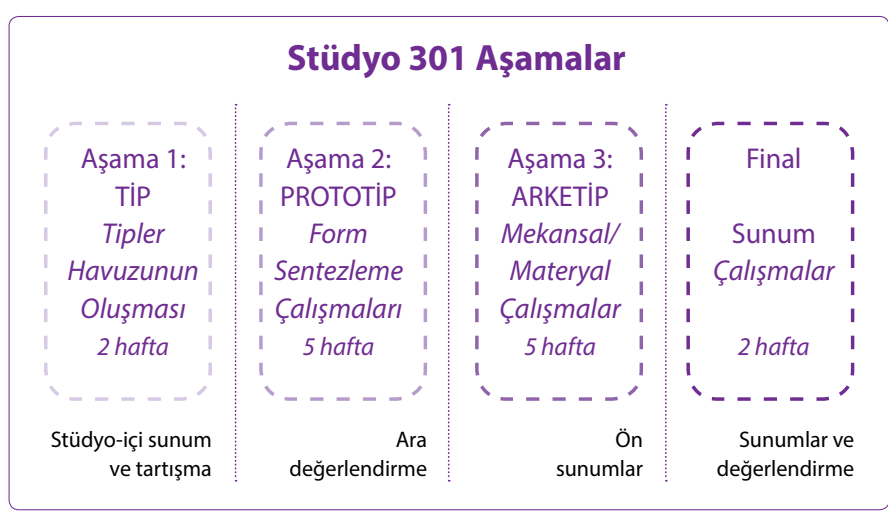

Şekil 2. Önerilen 14 haftalık programın aşamaları.

duğunu düşünen eğilimlerin farkında olduğuna işaret eder. Fakat, sunulan makaleler tip kavramının pedagojik potansiyeline ve tipin mimari tasarım süreçleri içinde kilit rolüne vurgu yapan bir derlemeyi oluşturur.

Yukarıda bahsedilen derlemenin içinde, Williams ve Scofidio'nun ${ }^{25}$ sunduğu pedagojik çerçeve bu makale için bahsedilmesi gereken bir yaklaşımı örnekler. Williams ve Scofidio, geçmişi neredeyse 40 yılı bulan bir birikime dayanan ve tipler ile veya tipler üzerinden düşünmenin stratejik bir biçimde tasarım eğitiminin içine sızdığı bir programdan bahseder. Buna göre öğrenciler, tip kavramı ekseninde tasarım eğitiminin temel meselelerini (temsil, ölçek, malzeme vb...) ele alırlar. Mimari mekân kurgusunun başlıca unsurlarını (duvar kolon, pencere, vb...) farklı temsil sistemleri üzerinden tekrar üretmeyi ve işlemeyi esas alan bu pedagojik çerçeve, sözü geçen nesnelerin daha soyut bir biçimde yorumlanmasına ve farklı bir araya geliş biçimlerinin araştırılmasına odaklanır.

Neredeyse yarım yüzyıl öncesinin pedagojik yaklaşımını örneklese de, Williams ve Scofidio'nun sunduğu yöntem, hesaplamalı tasarım ve üretim yönteminin baskın hale gelmeye başladığı günümüzün tasarım eğitimi için bir potansiyel taşımaktadır. Williams ve Scofidio'nun tipleri görece soyut olgular olarak ele alması, işlevsel yaklaşımın indirgemeci etkileri ile uzlaştırması ve tipolojik düşünceyi mimari tasarım süreçlerinde merkeze alması tasarım stüdyosu için hala geçerliliği olan bir perspektiftir. Bu görüşle, mimari tasarım süreçlerinin mekân, ölçek, strüktür gibi temel meselelerini tipler üzerinden araştrılabileceği bir pedagojik çerçeve oluşturulmuştur. Önerilen çerçeve program, mimarlık lisans seviyesinde üçüncü senelerini geçiren 46 kişilik bir öğrenci grubu ile 14 haftada tamamlanmıştır (Şekil 2).

Yürütülen uygulama, dönem öncesinde içeriği ve yürütücüleri ile tanımlanmıs ve katlımcıların tercih edebileceği diğer stüdyo grubu ile birlikte tanıtılmıştır. Bu bilgilendirme ile stüdyoya gelen öğrenciler, yukarıdaki grafikte belirtilen aşamalar için ilk haftadan itibaren dört yürütücü eşliğinde

\footnotetext{
${ }^{25}$ Williams ve Scofidio, 1982.
} 
çalışmışlardır. Bir sonraki kısımda, lisans düzeyinde yürütülen mimari tasarım stüdyosunda kurgulanan ve uygulanan programın kısa bir özeti verilecektir.

\section{Tip Odaklı Bir Tasarım Stüdyosu}

Rafael Moneo, ${ }^{26}$ tasarım sürecini bir tipolojiye ait elemanları, tekil bir ürünü ayırt eden kesinlik haline getirme yolu olarak tanımlar. Bu anlamda tiplerin tasarım süreçleri içinde dönüşerek ve her zaman doğrusal olmayan bir rotada ilerlediği düşünülebilir. Tasarımın, doğasında tekrarları ve belirli döngüleri barındırdığı düşünüldüğünde Moneo'nun işaret ettiği yöntem, tasarımcıların gündelik üretimlerini tarif etmesi anlamında önemlidir. Moneo'nun çerçevesi, Argan'ın tiplerin tasarımın farklı ölçeklerinde (yapı-yapı parçaları-elemanlar) alabileceği rolleri vurgulayan fikirlerinin ötesinde bir analitik seviye sunar.

Moneo'nun yaklaşımı, tipleri indirgeyici veya kısıtlayıcı olarak görmenin ötesinde, mimari tasarım eğitimi için pratik bir yöntem olarak bir potansiyel taşıyabilme sorusunu gündeme getirmiştir. Aşağıda detayları verilen pedagojik kurgu, tipleri tasarım süreci içinde eksen alan bir yöntemin araştırıldığı bir stüdyo uygulamasının ana hatlarını açıklar. Önerilen yöntem, tasarım öğrencilerinin farklı mekanizmalar üzerinden, tiplerin oluşumunu (tip), dönüşümünü (prototip), ve mekânsallaşmasını (arketip) deneyimlediği bir etaplar dizisi üzerinden ilerler. Ardışık ilerleyen bu kurgu, katlımcıların ilk adımda oluşturan tipleri temel biçimsel operasyonlarla -dijital veya fiziksel olarak- işlemesi (manipülasyon), dönüştürmesi ve birleştirmesi ile süreklilik gösterecek şekilde düşünülmüştür. Illk aşamalarda görece soyut oluşumlar olarak okunabilecek tipler, son aşamaya gelindiğinde belirli bir oran, malzeme ve işlev ile de ilişkilenebilecek detaydaki "arketipler" olarak yorumlanabilir.

Argan, ${ }^{27}$ tipoloji ilgili sorgulamanın, tasarımcıların düşünme ve iş üretme bağlamında geçerli bir araştırma alanı yarattğını söyler. Tipleri sadece bir sınıflama aracı veya tarihsel/analitik bir fenomen olarak görmeden, tasarım süreçleri içinde yaratıcılığı tetikleyici bir yöntemin asal parçası olarak kullanmak öngörülen pedagojik yaklaşımın temelini oluşturur. Burada tip başlangıçta soyut formasyonlar olarak ele alınmıştır. Ortaya çıkan tiplerin veya kompozisyonların tarihsel referansları olabileceği düşünülse de, aslında vurgulanmak istenen biçimsel, yapısal ve mekânsal özelliklerdir. Bu yaklaşım, Carlo Argan'ın makalesinde tipler için belirttiği kavramsal arka plan ile bir karşıtlık oluşturur. Argan tiplerin kabulünü her zaman mevcut bir seri yapının varlığı ile tanımlarken, denenmiş kurgular (a priori) olmadan herhangi bir tipin varlığından söz edilemeyeceğini önerir. Bu sayede yapılı çevreye, giderek de kentlere kazınan mimarlık bilgisinin tipler üzerinden sürekli kılınabileceğine vurgu yapar. Argan'ın çerçevelediği tanım,

${ }^{26}$ Moneo, 1978, s. $23 . \quad{ }^{27}$ Argan, 1996, s. 242. tip kavramına dair kabul görmüş (kanonik) bir tanım olarak ön plana çıkar. Fakat, gelişen temsil ve tasarım teknolojileri ile beslenen çağdaş yaklaşımlar içerisindeki çeşitlenmeler ve yeni yorumlar, tip için tanımlanan yerleşik çerçevenin ötesinde var olan denemelere de bir arka plan oluşturur. Önceki kısımlarda belirtilen "Klein Şişesi" örneği, mimarlık bağlamında herhangi bir öncülü olmayan bir topolojik nesne tipinin ${ }^{28}$ mekânsal-kurgusal potansiyelinin araştıılması adına bir tasarım uygulamasını temsil eder. Bu makalede sunulan pedagojik kurgu da, bu kavramsal esnemeyi bir firsat olarak görüp, tipleri tanımlayan tarihsel ve bağlamsal güçlerin vurgusunu, yeni tiplerin nasıl oluşabileceğini ve nasıl kullanılabileceğini görmek adına azaltmıştır.

Tipler üzerine oluşagelen terminoloji ile de ilişkilendirerek kurgulanan bu yapı üç katmanlı bir süreç -tip, prototip, arketip- üzerinde derinleşir. Bu katmanlar, tipleri (1) yaratma, (2) dönüştürme, ilişkilendirme ve sentezleme, (3) materyal ve mekânsal potansiyelleri ile beraber düşünmek için ayırt edilebilir parçalar halinde düşünülmüştür. Önerilen protokol doğrusal bir süreç olarak okunsa da, uygulama içinde tekrarlara ve geri dönüşlere olanak sağlamaktadır. Kurgulanan aşamalar, tiplerin yapısal-biçimsel anlamda bir araya gelmelerine ve mekânsal kurgunun özel parçaları olarak süreç içinde dönüşümlerini görünür kılmaktadır. Bu türden bir yaklaşımı, tiplerin kentsel bağlam ile ilişkisini ele alan Colin Rowe'un çalışmalarında zengin bir şekilde okumak mümkün.

Rowe, ${ }^{29}$ farklı temsil biçimlerini (şekil-zemin ilişkileri, aksonometrik perspektif) ve teknikleri (çözümleme-kolajçarpıştırma) kullanarak, tiplerin bağlam ve birbiri ile etkileşimlerini temel bir kompozisyon meselesi olarak mimari tasarım süreçlerinin merkezine alır. Rowe'un projelerinde "doğrusal" veya "çeper" bina tiplerinin kullanımının yanında daha karmaşık tarihsel prototiplerin ${ }^{30}$ baskın şekilde mimari çözümleri yönlendirdiği örnekleri görülebilir. Rowe'un öznel bir tercih ile belirli tipleri eksen alması, koruması ve farklı tasarım kararları çerçevesinde dönüştürmesi bu makalede önerilen pedagojik sistem için önemli bir uygulama katkısı olarak ele alınmıştır.

İlk aşamada katılımcılardan istenen, kullanılacak tiplerin yaratılması, temsil edilmesi ve tasarım süreçleri içinde kullanılacak bir tip havuzunun oluşturulmasıdır. Yöntemin bu ilk aşaması katilımcıların bilgisayar ortamında çalıştı̆ı ve hemen arkasından basit fiziksel maketler ürettiği bir süreçtir. ${ }^{31}$ Kullanılan görsel destekli tasarım yazılımlarının önerdiği formasyon rotaları takip edilerek tipler dijital ortamda yaratılmıştır (Şekil 3). Bu aşamada belirtilmesi

\footnotetext{
${ }^{28}$ Sürecin aktörleri tasarımcılar (UN ${ }^{30}$ Ellis makalesinde, Rowe'un kulStudio), Klein Şişesini bir "tip" ola- landığı prototiplere örnek olarak rak kategorize ettikleri için burada İtalya'dan Prato della Valle, Padua, da aynı sekilde kullanılması öngö- ve Isaola Bella'dan bahseder. rülmüştür.

${ }^{29}$ Ellis, 1998
} 


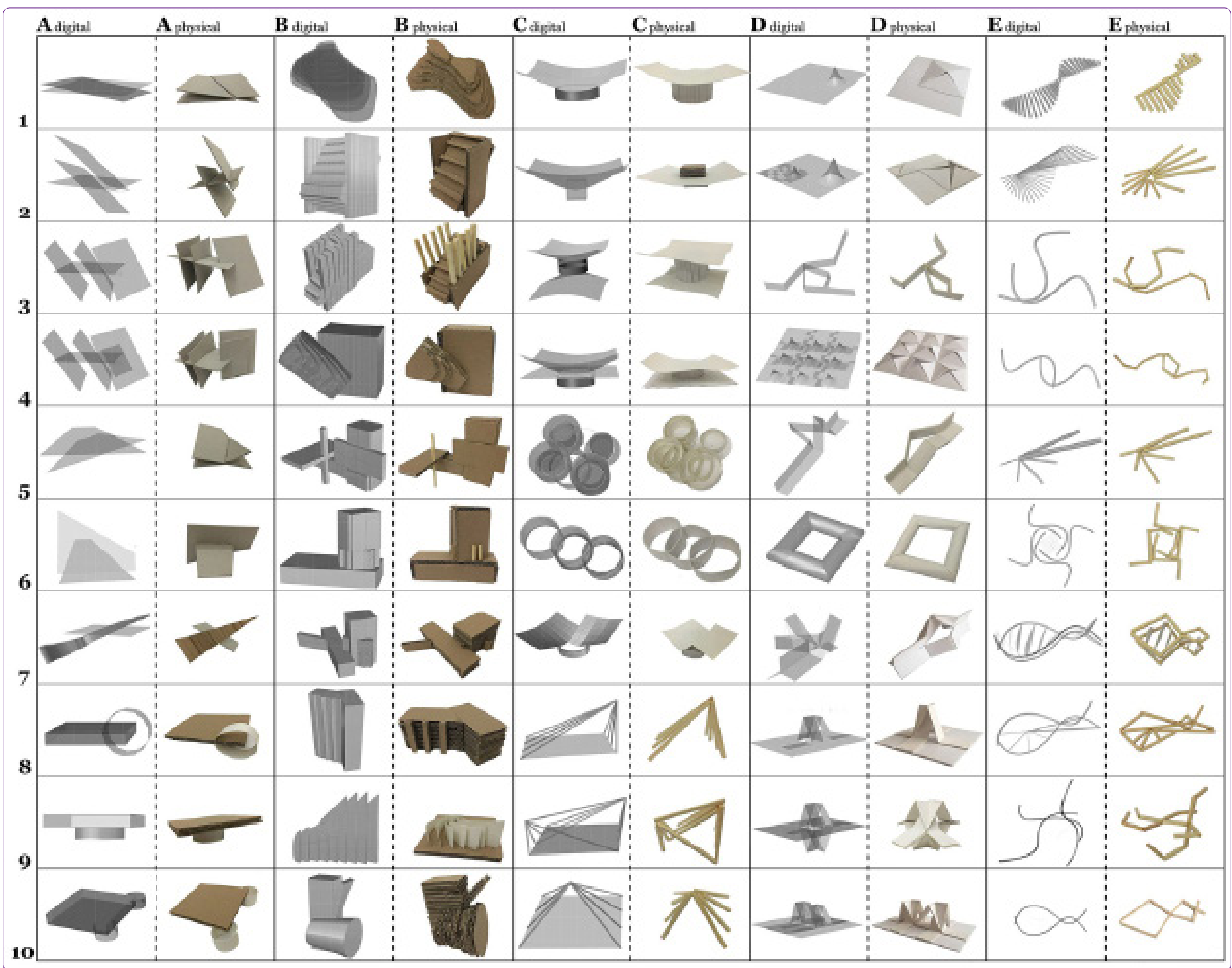

Şekil 3. Dijital yöntemlerle elde edilmiş, fiziksel maketleri ile beraber sunulmuş tipler sözlüğü.

gereken önemli noktalardan biri de yaratilacak setin parçalarının oluşumunda seçilen yazılımın ötesinde, benzeri yazılımların hemen hemen hepsinde bulunan form operasyon komutlarının belirleyici olmasıdır. Bu komutların (kopyala, sırala, döndür, katla, bük, ölçekle, aynala, traşla, vb...), katlımcılar tarafindan boyutları önceden belirlenmemiş çizgiler ve yüzeyler üzerinde uygulanıp bir kenarı 18 santimetreyi geçmeyecek bir küpün hacmini aşmayacak şekilde temsil edilmesi beklenmiştir. Dijital ortamda oluşturulan nesneler, üretilen fiziksel maketleri ile beraber düşünülüp son hallerini almışlardır. Her katıımcı için elli farklı parçadan oluşan bu sözlük, her zaman çok orijinal olmayan parçaları içerse de, tasarımın diğer süreçleri için bir altlık oluşturmaktadır. Katılımcılardan beklenen, üretilen her parçanın işlenebilir ve değerlendirilebilir nitelikleri olan bir tip olarak yorumlamalarıdır.

Güncel dijital tasarım uygulamalarında, yazılımların önerdiği doğrusal ve "farklı örüntülerin görülmesini en- gelleyen" süreçler eleştiri konusu ${ }^{32}$ olabilmektedir. Bu durumun farkında olarak, dijital tasarım araçlarının form üretme biçimleri, katılımcıların üzerinde çalışabilecekleri tip setlerini yaratmak için seçilmiştir. Bu yöntem, tipleri hazır olarak seçmeden/toplamadan, katılımcının morfolojiye dair parametrelerini kendi belirlediği bir uygulamayla elde edildiği için tercih edilmiştir. Her katılımcının oluşturduğu tip çeşitlemeleri, hem dijital hem de fiziksel temsillerle bir tipler sözlüğü (lexicon) haline getirilmiştir. Farklı temsil biçimleriyle katılımcıların repertuarında hazır hale gelen bu parçalar, tasarımın ilerleyen aşamalarını tetikleyen öncüller olarak ele alınmıştır.

İkinci aşamada, katılımcılardan ürettikleri tiplerin yapısal/kurgusal özellikleri incelenerek birden fazla tipi bir araya getirme denemeleri yapmaları istenmiştir. Sürecin bu kısmında temel amaç, tipleri biçimsel özellikleri göz önün-

\footnotetext{
${ }^{32}$ Sorguç, Özgenel, Yemiş̧̧ioğlu, 2018, s. 262.
} 
de bulundurarak dönüştürme, ilişkilendirme ve sentezleme mekanizmaları üzerinde yoğunlaşmak olmuştur. İlk aşamada oluşturulan iki veya daha fazla parçanın biçimsel olarak nasıl bir araya gelebileceği çalışılmıştır. Seçilen tiplerin birlikte düşünülüp dönüşmeye başladığı bu aşamada, farklı temsil biçimleri de kullanılmıştı. Ortaya çıkan prototipler aksonometrik perspektifler, diyagramlar, ve karton maketlerle temsil edilmiş, ve katılımcılara başka bir medya üzerinden tasarımları tekrar değerlendirme firsatı yaratmıştr. Bu anlamda, üretilen prototipler, temsil edildikleri medya değişse de biçimsel olarak statik kalmamaları sağlanmıştır (Şekil 4).

Stüdyo içi tartş̧malarda bu prototiplerin tektonik özellikleri vurgulanırken mekânsal kullanım/program anlamında bu hacimlerin tanımlı bir işleve referans vermesine dair düşünceler öncelikle düşünülen bir mesele olmamıştr. Katılımcıların bu aşamada alternatif formasyonları (prototipleri), bir araya gelme biçimleri önemsenecek şekilde değerlendirerek farklı temsil sistemleri üzerinde tekrarlamaları ve dönüştürmeleri istenmiştir. Böylece katılımcıların kendilerine has bir tasarım dilinin oluşabilmesinin ipuçları araştrıılır. Ayrıca, bu yöntemle, prototiplerin bir kesinlik yaratmasından çok ilerleyen aşamalardaki mekânsal alternatifleri araştırmak için bir altlık olmaları öngörülmüştür. Bir diğer deyişle elde edilen prototipler, farklı biçimsel müdahalelere hala izin verebilecek şekilde sentezlenen jenerik diyagramlar olarak düşünülmüştür. Katlımcılar açısından elde edilen temsillerin bitmiş ürünler olarak görülmemesinin sağlanması, tasarım anlamında oluşabilecek tıkanıklıkların önüne geçmiştir.

Üçüncü aşamayı ise elde edilen kompozisyonların birer arketip olarak değerlendirilmeye başlandığı bir araştırma süreci oluşturmuştur. Bu son etapta, arketip teriminin mimarlık, psikoloji ve başka disiplinlerdeki anlam farklılaşmalarının bilincinde olarak eldeki prototipler daha rafine bir kompozisyon stratejisi üzerinden fonksiyon ve tektonik ifade ile ilişkilendirmeye çalışılmıştır. Arketip teriminin çağrıştırdığı kapalı sistemlerin, doğru yanlış ikilemlerinin veya normatif değerlendirmelerin ötesine geçme çabası ön plana çıkartılmıştır. Bu genel yaklaşımı takip ederek, uygulama ölçeğinde, oluşturulan üç boyutlu geometrilerin mekânsal karakterleri korunarak, yapısal karakteri (malzeme) ve kullanım ilişkileri (işlev) açısından tekrar değerlendirilmesi ve dönüştürülmesi önemsenmiştir. Bu etabın sonunda ulaşılması istenen noktada ise her katılımcının belirgin bir tektonik ifade ve işlev için ideal bir örnek kurgunun önerilmesi düşünülmüştür.

Stüdyo içi tartş̧malardaki ana hedef arketiplerin mimari mekânları daha detaylı biçimde tanımlanabileceği bir rota izlemektir. Bu anlamda katlımcılar, eldeki arketiplerin materyal ve mekânsal potansiyellerini keşfederken aynı zamanda kendi belirledikleri bir kullanım (işlev) ajandası oluşturmaları beklenmiştir. Ele alınan kompozisyonlar içinde kullanılan tiplerin veya prototiplerin ilk oluştukları

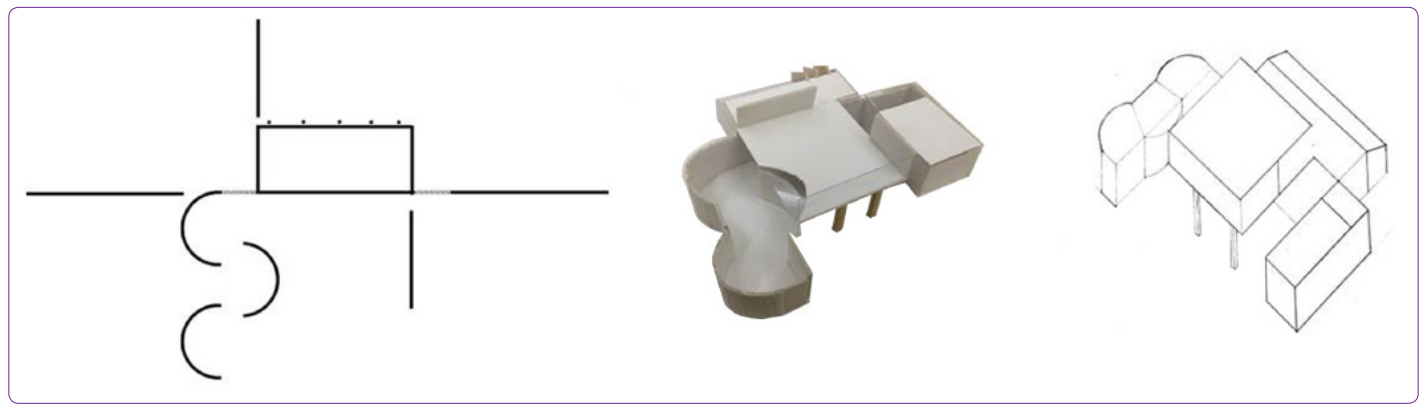

Şekil 4. Farklı medya üzerinden (diyagram, maket, aksonometrik) temsil edilen prototipler.

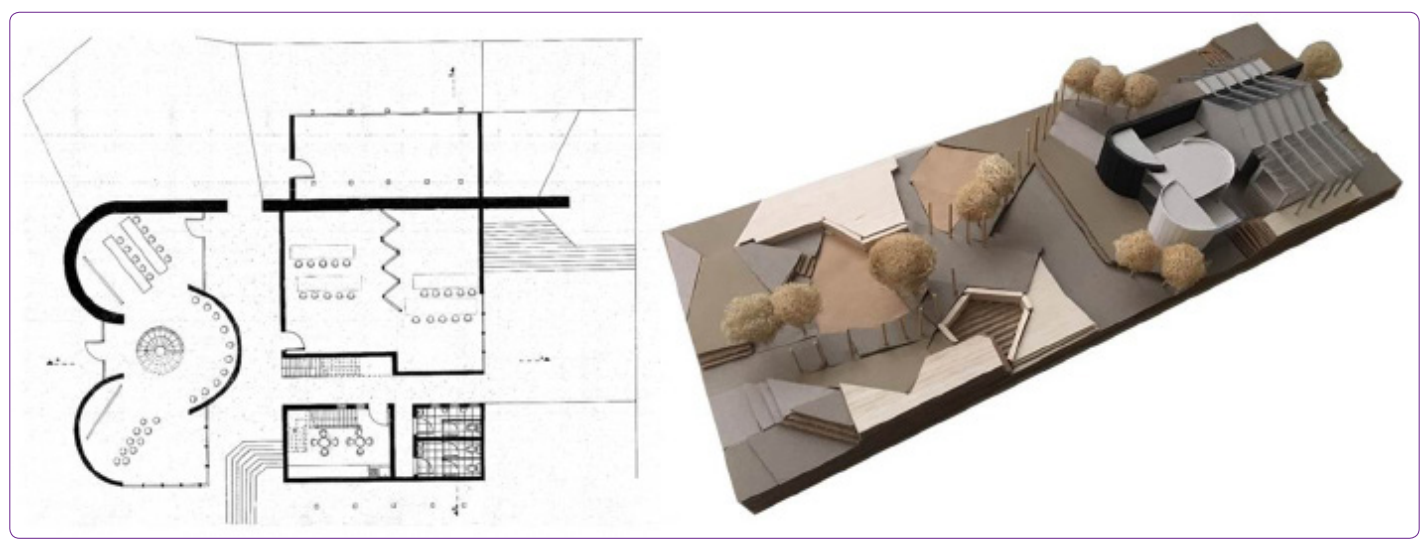

Şekil 5. Elde edilen arketiplerin çizim ve maket üzerinden ifade edilmesi. 


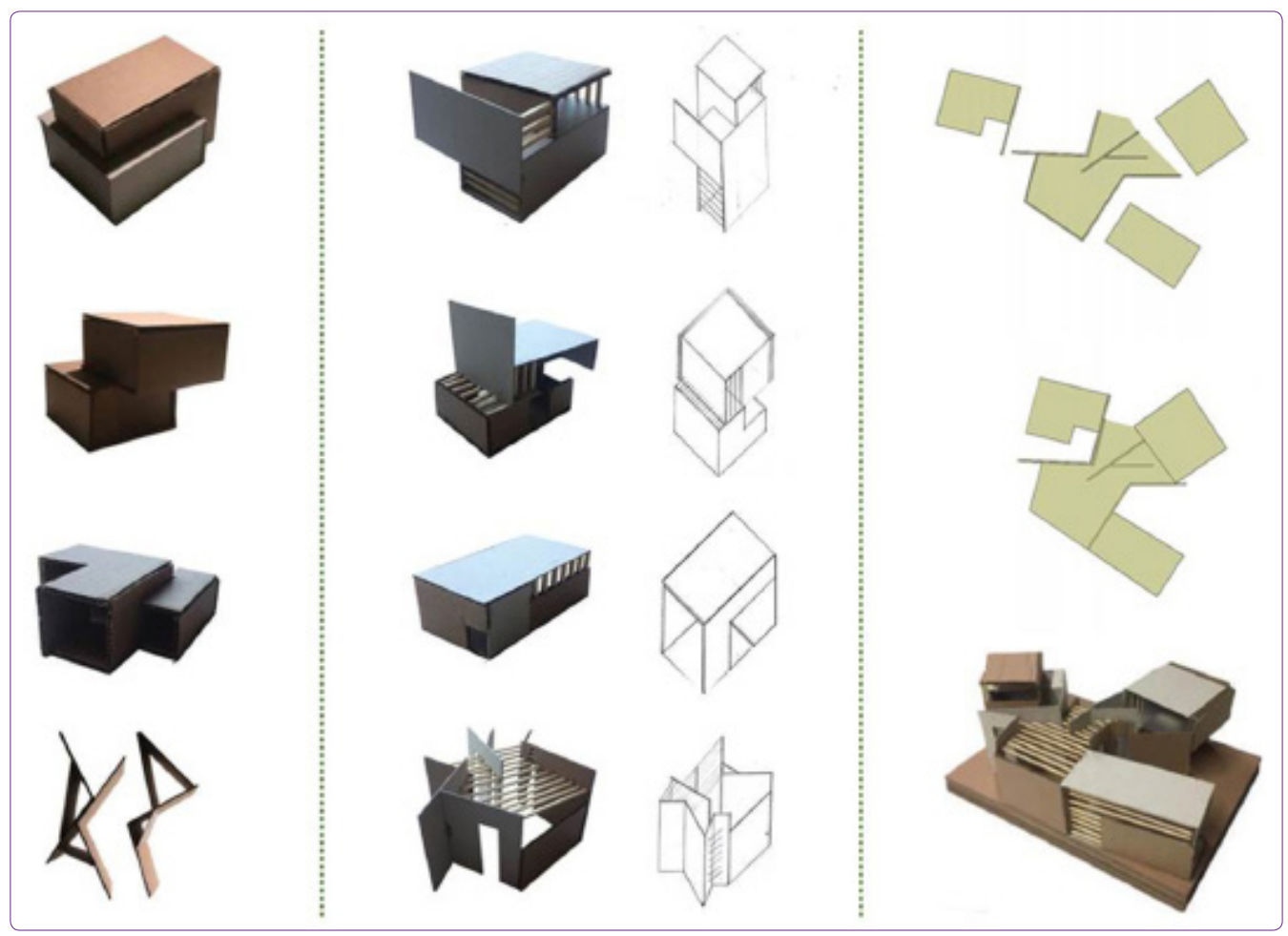

Şekil 6. Süreç içerisindeki farklılaşma ve çeşitlenmeleri görünür kılan seyir defterlerinden bir sayfa.

biçimleriyle okunur kılınması -veya tersi için- özel bir çaba sarf edilmemiştir.

Tasarlanan sürecin erken aşamalarında kullanılan tiplerin biçimsel karakteri ve birden fazla tipin oluşturduğu kompozisyonların yapısal özellikleri tartş̧ılırken, son aşamada ise eldeki arketipin mekânsal varlığından ve potansiyel mekânlar dizilerinin birbiri ile ilişkisinden bahsedilmiştir. Stüdyo yürütücüleri ve katılımcılar arasındaki tartışmalar, arketiplerin yeni bir okunmasının sağlanması için bir altyapı oluştururken, aynı zamanda elde edilen temsillerin dönüşmesinin sürekliliğini sağlamıştır. Bu dönüşümü takip edebilmek için, daha önce kullanılan temsil sistemlerine ek olarak, katlımcılardan ortografik çizimlerin (plan-kesit-görünüş) üretilmesi istenmiştir (Şekil 5). Üretilen çizimler, bu arketipler özelinde katılımcıların mekânsal algılarının oluşmasına katkıda bulunurken, mimari mekâna dair kalitelerin (oran, ölçek, doku, vb...) gelişmesini sağlamıştir. Son ürünlere yaklaşttkça, tipler üzerinden başlayan kurgunun, farklı temsil sistemleri üzerinde mimari mekân olarak okunmaya başlandığı bir kompozisyona ulaşmaya başladığı görülmüştür.

Ortaya çıkan ürünlerin daha kapsamlı bir şekilde yorumlanabilmesi ve deneyimlenen tasarım sürecine dair farkındalığı arttırabilmek için katılımcılardan dönem boyunca ürettikleri maketler ve çizimler için bir seyir defteri tutmaları istenmiştir. Bu seyir defterleri tasarımın dönüşmesindeki belirli eşik noktalarını belirlemek ve alınan kararları tekrar değerlendirebilmek için referans noktalarını belirgin kılmıştır. Aynı zamanda da ulaşılan mimari kompozisyonların, tipler, prototipler ve arketipler olarak adlandırılan aşamalarda biçimsel olarak nasıl değiştiğini okunur kılabilecek bir arşiv oluşturmuştur (Şekil 6). Bu anlamda oluşturulan "anlatllar," önerilen pedagojik kurgunun amaçları doğrultusunda, son ürüne odaklanmaktan öte, deneyimlenen süreci vurgulamayı hedeflemiştir. Katılımcıların ilk aşamada oluşturdukları tiplerin bireysel tasarım süreçleri içerisinde nasıl dönüştüğü ve çeşitlendiğine dair derin bir irdeleme bu makale kapsamında yapılmamıştr. Bu doğrultuda, önerilen kurgunun her aşaması için bir yürütülebilecek bir inceleme, tip-odaklı bir tasarım yaklaşıma ilişkin daha zengin bir bakış açısı sunma potansiyeline sahiptir.

\section{Değerlendirme ve Sonuç}

Tip ve tipolojik düşünmeyi merkeze alan çok katmanlı bir kurgunun şekillendirdiği stüdyo çalışması, konu üzerine literatürde belirtilen bazı önermeler ve kabullerle paralellik göstermektedir. Öncelikle, önerilen tasarım süreci, Argan'ın yazdıklarına referansla tip kavramını ve materyal karşılığını farklı ölçeklerde formüle edilebilecek ve bu ölçekler arasında geçişlere olanak verecek bir yaklaşıma referans verir. Bu düşünce ile oluşturulan biçimlerin yapısal özellikleri ve bu parçaların bir araya gelebilme olanakları farklı temsil biçimleri üzerinden değerlendirilerek son ürünlere ulaşılmıştır. Takip edilen tasarım yöntemi, katlımcıların biçim üretebilme ve ürünleri farklı medya üzerinden temsil edebilme bağlamında hâkim olabileceği ölçekler üzerinden ilerlemiştir. Bununla birlikte, ayırt edilebilir 
etaplar (tip, prototip, arketip) üzerinden ilerleyen yöntem, tasarımcı açısından adımların farkında olma ve aşamaları sorgulayabilme firsatı tanımıştır.

Yukarıda bahsedilen yaklaşım Argan'ın ${ }^{33}$ tip kavramı üzerine söyledikleri ile bir anlamda paralellik göstermektedir. Fakat önerilen kurgunun ele aldığı tip kavramı, Argan'ın yorumladığı tip ile ontolojik ve epistemolojik bir farklılığı içermekte olduğunu da vurgulamak gerekiyor. Argan, tiplerin kabulünü her zaman mevcut bir seri yapının varlığı ile tanımlarken, denenmiş kurgular (a priori) olmadan herhangi bir tipin varlığından söz edilemeyeceğini önerir. Bu sayede yapılı çevreye, giderek de kentlere kazınan mimarlık bilgisinin tipler üzerinden sürekli kılınabileceğine vurgu yapar. Argan'ın çerçevelediği tanım, tip kavramına dair kabul görmüş bir tanım olmakla birlikte, bu görüşe karşı geliştirilmiş eleştirel bir damarın da olduğundan söz etmek gerekiyor. Rafael Moneo'nun 1978 tarihli makalesinde ${ }^{34}$ izlerini okuyabileceğimiz bu karşı görüş, tipleri "donmuş mekanizmalar" olarak tanımlar ve özellikle mimarlık bağlamında tasarımcıların yerleşik tipleri yeniden ele alma veya dönüştürme eğilimlerine vurgu yapar. Bu çaba, tipleri sadece inşa edilmiş ya da edilmemiş, bir seri yapı grubu üzerinden formüle etmeyen, görece ilerici bir tutumdur. Bu makalede sunulan pedagojik yaklaşım ise yukarıda bahsedilen bu iki çerçevenin (donmuş mekanizmalar olarak tipler ve öncüller üzerinden düşünülmeden potansiyellerin araştrılabileceği bir altlık olarak tipler) uygulamada birbiri ile uzlaşabileceği bir kanala işaret edebilmesindedir. Burada sözü edilen uzlaşmadan kasıt, bütün veya parçalar halinde ele alınan morfolojilerin, belirgin öncüllere referansla veya herhangi bir bağlamsal arka plana işaret etmeden de tasarım süreçleri içerisinde farklı kurguların oluşmasında veya istenilen mekânsal etkilerin elde edilmesinde kullanılabiliyor olmasıdır. Bu durum tiplerin tasarım süreçleri içerisinde kullanılmasının görece muhafazakâr sayılabileceği yönündeki görüşlere bir cevap olabilmesi anlamında önemli bir tartş̧maya işaret eder.

Bu tartışmanın ötesinde vurgulanması gereken bir nokta da tiplerin -bir öncül ile ilişkilensin veya ilişkilenmesin-, işlenebilir veya tekrar değerlendirilebilir nitelikleri olduğu konusudur. Bu makalede fazla işlenmemiş olsa da, önerilen kurgunun hipotezlerinden biri de, adı geçen mimarların en iyi örneklerini verdiği üzere, tiplerin tasarımcılar tarafindan benzer bilişsel (cognitive) yöntemlerle tarafindan işlendiği, tekrar işlendiği, dönüştürüldüğü ve ve uyarlandığı görüşüdür. Bu yaklaşımla tipler, mimarın vizyonu dâhilinde -bir kural takip edecek veya etmeyecek şekilde- dönüştürülmüş ve temsil edilmiş parçalardır. Stüdyo kurgusu da bu dönüştürme operasyonlarını bir beceri seti olarak görüp, bunu bir egzersizler seti haline getirme kaygısı ile oluşturulmuştur.

\footnotetext{
${ }^{33}$ Argan, $1996 . \quad{ }^{34}$ Moneo, 1978, s. 27
}

Tiplerin, mevcut yapılar ile ilişkilensin veya sıfirdan üretilsin, tasarımcılar için "üretken" bir kaynak olması durumu, güncel tasarım yöntemleri üzerine yapılan araştrrmalar için de anlamlı bir tartş̧ma konusudur. Bu anlamda, makalede sunulan pedagojik yaklaşımın yorumu için farklı rotalar önerilebilir. Örneğin, üretilen biçimsel havuzun nası tanımlanacağı kritik bir araştırma sorusu olarak karşımıza çıkar. Güncel tasarım yaklaşımları bağlamında, benzeri morfolojilerin tip, şema, veya diyagram olarak adlandırıldığı örnekler bulunabilir. Kullanılan bu üç terimin de üretilen kataloğun parçalarını açıklama potansiyeli olduğu kabul edilse de tasarım bağlamında tip kapsayıcı arka plan tartışmaları ile en azından önerilen pedagoji için en uygun tanımlamayı sağlamıştır. Örneğin, Lawson'un da makalesinde irdelediği şemalar tasarımcıların arasındaki iletişimi destekleyen bir olgu olarak tanımlanır. ${ }^{35}$ Semalar, daha sıkı bir kurallar dizisine bağlı bir süreç ile tanımlanırken ve biçimsel olarak daha kapalı sistemleri işaret ettiği savunulabilir. Öte yandan, güncel tasarım kuramalrı içinde daha fazla ilgi çeken diyagramlar ise görece daha üretken bir tasarım yöntemine işaret eder. Fakat, soyut, kavramsal ${ }^{36}$ ve üretken ${ }^{37}$ potansiyellerinin tasarım süreçleri içindeki rolü çeşitli araştırmalarla vurgulansa da, genelde materyalden bağımsız bir gerçekliğe referans vermeleri diyagramları tiplerden farklı bir analitik düzlemde görmemizi sağlar. Tip, şema, ve diyagram ekseninde bu türden bir karşılaştırmalı analiz daha derin bir tartsşmayı hak etmektedir. Bu makale bağlamında vurgulanmak istenen ise, mimarlık kuramı ve uygulaması kapsamında üretilen kapsayıcı arka planı ve bu zengin arka plan içerisinde temsil yöntemlerine, biçimsel potansiyellere ve materyal kapasitelere ilişkilenebilen tartışmalar sayesinde tip kavramının pedagojik yaklaşım içerisinde anlamlı bir çerçeve oluşturabildiğidir. Bu çerçeve içerisinde üretilen tipler sözlüğü (lexicon) ise, tecrübeli tasarımcıların repertuarlarında farklı anlamlara veya yorumlara olanak verebilecek şekilde bulundurabildiği bir form havuzunun, disiplin içerisinde acemi diyebileceğimiz tasarımcılar için kendi kabiliyetlerini test edebilecekleri ve geliştirebilecekleri bir biçim kataloğu olarak okunabilir. Kullanılan form havuzu, bu yönüyle de, Frascari'nin betimlediği şekilde Scarpa'nın detayları ve formları kullanma ve anlamlandırma yöntemine paralellik gösterir. ${ }^{38}$

Önerilen pedagojik kurgunun literatür ile ilişkilenen önemli bileşenlerinden biri ise tip anlayışının biçimsel tezahürlerinin farklı mimarlarda farklı temsillerde işlenmesidir. Illk kısımlarda verilen örneklere (Rossi, Moneo, UNStudio) dayanarak, kurgulanan süreçte oluşturulan morfolojilerin farklı medya üzerinden okunabilir kılınması planlanırken, süreç içerisindeki müdahalelerle oluşacak biçimsel dönüşümler teşvik edilmiştir. Katılımcılar, kendilerine sunu-

\footnotetext{
35 Lawson, 2004, s. 446.

${ }^{36}$ Dogan \& Nersessian, 2012.
} 
lan rotaları (tip, prototip, arketip) takip ederek elde edilen ürünlerin üzerinde uygulanabilecek biçimsel işlemler (manipülasyonlar) için farklı olanakların ve temsillerin araştrııması için yönlendirilmişlerdir. Bu anlamda tasarım süreçleri için tikanma veya saplanma (fixation) durumları katılımcının kendisi tarafindan, çoğunlukla bir dış müdahaleye gerek kalmadan, aşılabilmiştir. Kurgulanan bu deneyim, tasarım eğitimi açısından, tasarım öğrencilerinin, tasarım sorunlarını otonom çözebilme becerisini kazandırma anlamında değerlidir.

Tipleri odak alan literatürde vurgulanan önemli meselelerden bir diğeri de elde edilen tasarımların tipler üzerinden nasıl türediği veya üretildiğidir. Rafael Moneo, ${ }^{39}$ tasarımcının tipler ile çalışmaya başlayıp, tiplerin biçimsel-yapısal karakterleri üzerinde yaptı̆ı müdahalelerin, yeni tiplerin oluşmasına olanak verdiğinden bahseder. Moneo'nun biçimsel-yapısal tanımlaması, tipleri temsil eden soyut bir geometrik tanımın ötesinde, tiplere gerçeklik kazandıran materyal özellikleri de içerir. Moneo'nun tanımı ile tipler, saf düşünsel olgular olmak yerine fiziksel karşılıkları da bulunan olgular olarak tasarımcının repertuarında yer alır. Bu makalede bahsedilen ve uygulanan pedagoji de tiplerin biçimsel-yapısal kurgularının sorgulanabilmesi ve değiştirilebilmesi için ilk aşamadan itibaren fiziksel maketlerin kullanılmasını önerir (Şekil 2-4). Katılımcıların, herhangi bir malzeme kısıtlaması olmadan, ele alınan tipleri maketler üzerinden yorumlaması, süreç içinde oluşan ve dönüşen ürünlerin biçimsel anlamda daha geniş bir yelpazeye yayılmasına sebep olduğu düşünülmüştür. Katılımcıların ürettikleri üzerinden yapılabilecek bir analiz bu çeşitlenmenin boyutlarını aydınlatmak için önemli bir kaynak oluşturulduğu düşünülmüştür. Fakat bu çeşitlilik üzerinden yapılacak bir irdeleme için farklı bir okumanın ve yöntemin geliştirilmesi bu araştırmanın bir sonraki adımı olarak planlanmıştir. Bununla beraber, tasarım bağlamında gerçekleşen bu çeşitlenmenin stüdyo uygulamaları içerisinde son derece görünür olduğu, ve katılımcıların bu gözlemlenebilir farklılaşma içerisinde tasarım süreçlerinin doğasına dair bir farkındalık geliştirdiği söylenebilir. Benzer tip havuzları ile başlayan süreçlerin farklı mimari ürünlere doğru evrilmesi, sınıf içi tartışmaların önemli noktalarından biri olmuştur.

Takip edilen yöntem, katilımcılara ilk aşamalardan itibaren benzer parametreler ve temsil araçları kullanmayı empoze etse de, son ürünlerdeki farklılık dikkat çekici boyuta ulaşmıştr. Bu anlamda tasarımların ıraksak olma hali, tiplerle çalışmanın kısıtlayıcı olup olmadığı üzerine olan tartı̧mayı tekrar gündeme getirmiştir. Tipler ve tasarım metodu üzerine, tartışmanın en yoğun olduğu yıllarda yazan Alan Colqhuoun, ${ }^{40}$ tasarımcıların her ne kadar belirgin bir (bilimsel) yöntem takip etseler veya mevcut tipleri temel alarak tasarlasalar da, tasarım süreci içinde her zaman sezgi-

\footnotetext{
${ }^{39}$ Moneo, 1978, s. 24.
}

sel tercihlerin yapıldığı alanların bulunduğundan bahseder. Mimari mekânın oluşumunda da takip edilen yöntemler, işlevsel veya performans anlamında belirgin farklar içermeyen alternatifler arasında tercih yapmak için her zaman yardımcı olmayabilir. Bu anlarda oluşan biçimler üzerine verilen kararların, ve daha genelde takip edilen kompozisyon niyetlerinin yol açthğı farklılaşma bu makalede sunulan pedagojik yaklaşım içerisinde de gözlemlenmiştir. Benzer bir havuz ile başlayan (Şekil 2) tasarım süreçlerinin, belirlenen çerçeve içerisinde ilerleyerek ayrıksı ürünlere dönüşmesi, Colquhoun'un belirttiği gibi sezgisel eğilimlerin veya yaratıcı düşüncenin tasarım süreçleri içindeki azımsanmayacak rolüne işaret etmektedir.

Önerilen sürecin görünür kazanımlarından biri ise, özellikle son aşamada (arketip) tasarım problemi olarak katlımcılara sunulan meselelerden biri olan ölçek kavramı ile ilişkilidir. Ölçek anlamında çok sorgulanmadan üretilen tip havuzunun, ve sonrasında ele alınan tiplerin bir araya gelebilme meseleleri son aşamada bu oluşumların bir mekânsal karşılığı olabileceği araştırılmıştır. Bu anlamda ölçek, malzeme ve mekânsal kurgu sorgulamaları sırasında üretilen farklı mekânsal temsillerin (ortografik, aksonometrik, veya maket) temel ölçek hatalarını barındırmadığı gözlenmiştir. Ölçek açısından gelişen bu tür bir farkındalık, katılımcıların mekâna dair sözlü sunumlarında da gözlenmiştir.

Yukarıda yapılan değerlendirmeler, temel olarak stüdyo süreci içerisindeki ve sonrasındaki gözlemlere ve anekdotlara dayanmaktadır. Kırkalt katılımcı ile yürütülen bu deneysel pedagojik sürecin sonuçlarına dair yapılan yorumlar elbette ki daha derin bir araştırmanın gerekliliğini göstermektedir. Tipler ve tasarım ilişkisi üzerine yapılacak daha kapsamlı bir saha araştırmasının ötesinde, konuyu gelişen tasarım yöntemleri ve yaklaşımları (örneğin hesaplamalı veya parametrik tasarım) açısından kuramsal olarak da irdelemek alana katkı yapacaktır. Tipler üzerine elli yıldır yapılan ve tekrar canlanma potansiyeli bulunan bu tartş̧manın farklı tasarım alanları için de ilgi çekici olacağı açıktır.

\section{Kaynaklar}

Argan, G. C. (1996) “On the Typology of Architecture”, Ed.: K. Nesbitt (editör), Theorizing a New Agenda for Architecture: An Anthology of Architectural Theory 1965-1995, New York, Princeton Architectural Press, s. 242-246.

Bos, C., \& van Berkel, B. (2011) "Typological Instruments: Connecting Architecture and Urbanism", Architectural Design, Sayı 81(1), s. 66-77.

Carl, P. (2011) "Type, Field, Culture, Praxis", Architectural Design, Sayı 81(1), s. 38-45.

Colquhon, A. (1969) "Typology and Design Method", Perspecta, Sayı 12, 71-74.

Durand, J.-N.-L. (2000) Précis of the Lectures on Architecture: With Graphic Portion of the Lectures on Architecture (Ingi-

\footnotetext{
${ }^{40}$ Colquhon, 1969, s. 71
} 
lizceye çeviren: D. Britt, Trans.), Los Angeles, Getty Research Institute.

Dogan, F., \& Neressian, N. (2012) “Conceptual Diagrams in Creative Architectural Practice: the Case of Daniel Libeskind's Jewish Museum", Architectureal Research Quarterly, Sayı 16(1), s. 14-27.

Ellis, W. (1998). "Type and Context in Urbanism: Colin Rowe's Contextualism", Ed.: K. Michael Hays (editör), Oppositions Reader: Selected Readings from a Journal for Ideas and Criticism in Architecture, 1973-1984, New York, Princeton Architectural Press, pp. 226-251.

Forty, A. (2000). Words and buildings: a vocabulary of modern architecture. New York: Thames \& Hudson.

Frascari M. (1996) “The Tell-the-Tale Detail”, Ed.: K. Nesbitt (editör), Theorizing a New Agenda for Architecture: An Anthology of Architectural Theory 1965-1995, New York, Princeton Architectural Press, s. 498-515.

Jacoby, S. (2015a) "Typal and Typological Reasoning: A Diagrammatic Practice of Architecture", The Journal of Architecture, Sayı 20(6), s. 938-961.

Jacoby, S. (2015b) "Type Versus Typology Introduction", The Journal of Architecture, Sayı 20(6), s. 931-937.

Lawson, B. (2004) "Schemata, gambits and precedent: some factors in design expertise", Design Studies, Sayı 25, s. 443-457.

Moneo, R. (1978) “On typology”, Oppositions, Sayı 13, s. 23-45.
Moneo, R. (2015) "Typology in the Context of Three Projects: San Sebastian, Lacua, Aranjuez", The Journal of Architecture, Sayı 20(6), s. 1067-1087.

Morris, E. K., \& Levin, E. (1982). Prologue: On the Discipline of Architecture. Journal of Architectural Education, 35(2), 1.

Ozdemir, B., \& Onal, F. (2016) “Mimari Tasarımda Sıralı Form Oluşum Diyagramları”, Megaron, Sayı 11(2), s. 230-240.

Pevsner, N. (1976). A History of Building Types. Princeton, Princeton University Press.

Picon, A. (2014) "Dom-Ino: Archetype and Fiction", Log, Sayı (30), s. 169-175.

Quatremère de Quincy, A. C. (1832), "Type" in Dictionnaire Historique de l'Architecture, (s. 629-630). Paris.

Rossi, A. (1982) The Architecture of the City. Cambridge, MIT Press.

Sorguç, A. G., Özgenel, Ç. F., \& Yemişcioğlu, M. K. (2018). Patterns of mind, patterns in design. Dönüştürülebilir Mekanlar: XII. Mimarlıkta Sayısal Tasarım Ulusal Sempozyumu Bildirileri, s.260-269, SDÜ, Isparta.

Vidler, A. (1996). "The Third Typology", Ed.: K. Nesbitt (editör), Theorizing a New Agenda for Architecture: An Anthology of Architectural Theory 1965-1995, New York, Princeton Architectural Press, s. 258-263.

Williams, T., \& Scofidio, R. (1982) "Typology and Primary Elements", Journal of Architectural Education, Sayı 35(2), s. 8-9. 